\title{
Correction to: Unusual complications following left ventricular assisted device implantation: case series
}

Amjad Shalabi 1,2,3,4* Erez Kachel 1,2,3,4, Yigal Kassif ${ }^{1,2}$, Muin Faqeeh ${ }^{1,2}$, Preisman Sergey ${ }^{2,5}$, Leonid Sternik ${ }^{1,2}$, Liza Grosman-Rimon ${ }^{3,4}$, Wadi Kinany ${ }^{3,4}$, Offer Amir ${ }^{3,4}$, Eilon Ram ${ }^{1,4}$, Jacob Lavee ${ }^{1,2}$ and Avishay Grupper ${ }^{1,2}$

\section{Correction to: Journal of Cardiothoracic Surgery (2021) 16:70 https://doi.org/10.1186/s13019-021-01445-7}

The original article [1] contained an error in co-author, Eilon Ram's name which has since been corrected.

\section{Author details}

${ }^{1}$ Department of Cardiac Surgery, Chaim Sheba Medical Center,

Tel-Hashomer 52621, Ramat-Gan, Israel. ${ }^{2}$ Affiliated to Sackler Faculty of Medicine, Tel Aviv University, Tel Aviv, Israel. ${ }^{3}$ Cardiovascular Department and Research Center, Poriya Medical Center, Tiberias, Israel. ${ }^{4}$ Affiliated to the Azrieli Faculty of Medicine, Bar-llan University, Safed, Israel. ${ }^{5}$ Department of Anesthesia, Chaim Sheba Medical Center, Tel-Hashomer 52621, Ramat-Gan, Israel.

Published online: 06 September 2021

\section{Reference}

1. Shalabi A, et al. Unusual complications following left ventricular assisted device implantation: case series. J Cardiothorac Surg. 2021;16:70. https:// doi.org/10.1186/s13019-021-01445-7.

\section{Publisher's Note}

Springer Nature remains neutral with regard to jurisdictional claims in published maps and institutional affiliations. original author(s) and the source, provide a link to the Creative Commons licence, and indicate if changes were made. The images or other third party material in this article are included in the article's Creative Commons licence, unless indicated otherwise in a credit line to the material. If material is not included in the article's Creative Commons licence and your intended use is not permitted by statutory regulation or exceeds the permitted use, you will need to obtain permission directly from the copyright holder. To view a copy of this licence, visit http://creativecommons.org/licenses/by/4.0/. The Creative Commons Public Domain Dedication waiver (http://creativecommons.org/publicdomain/zero/1.0/) applies to the data made available in this article, unless otherwise stated in a credit line to the data. 